\title{
Hellenic Verse and Christian Humanism: From Nonnus to Musurus
}

\author{
Filippomaria Pontani ${ }^{1}$
}

(C) Springer Science+Business Media B.V., part of Springer Nature 2018

'By Apollo, no true Greek would suffer a line of yours to pass his lips!' Henrik Ibsen, Emperor Julian, act III, sc. 2 (Julian to Apollinaris)

\section{Hellenic and Christian Poetry in Late Antiquity}

The last decades have witnessed a radical reappraisal of the role of Hellenism in the culture of late antiquity, especially in regard to art, literature and poetry: I am referring to the path-breaking work by scholars such as Glen Bowersock, Alan Cameron and Gianfranco Agosti. ${ }^{1}$ The traditional view of a stern ideological opposition between paganism and Christianism has shifted towards a framework of fluidity and interconnection, in which fragments of the old, Hellenic heritage could be freely re-used either in order to ensure a form of continuity with ethnic cults and practices (the cases of Egypt and Syria are particularly remarkable in this respect) or by way of contrasting imitation and allusive game. The Greek language and the pagan tradition represented a flexible instrument of cultural expression, easily adopted by different Mediterranean peoples despite differences of religious belief.

\footnotetext{
1 Useful, updated overviews: A. Cameron, 'Poetry and Literary Culture in Late Antiquity', in Approaching Late Antiquity, ed. S. Swain, Oxford, 2004, pp. 327-54; G. Agosti, 'Greek Poetry', in Oxford Handbook of Late Antiquity, ed. S. F. Johnson, Oxford, 2012, pp. 361-404 (361-3 on the recent studies); G. Agosti, 'Greek Poetry in Late Antique Alexandria: Between Culture and Religion', in The Alexandrian Tradition, ed. L. A. Guichard et al., Berne, 2014, pp. 287-311; G. Agosti, 'Cristianizzazione della poesia greca e dialogo interculturale', in Pagans and Christians in the Roman Empire, ed. P. Brown and R. Lizzi Testa, Zurich and Münster, 2011, pp. 193-214; for a less optimistic perspective, however, see G. A. Cecconi, 'Contenuti religiosi delle discipline scolastiche', ibid., pp. 224-43.
}

Filippomaria Pontani

f.pontani@unive.it

1 Dipartimento di Studi Umanistici, Dorsoduro 3484/D, 30123 Venice, Italy 
Students of early Byzantine art have grown more accustomed to figurative contamination between Orpheus and Christ, Dionysus and Christ, Leda (or Dionysus) and the Virgin Mary, ${ }^{2}$ and therefore more open to this critical perspective, in the wake of Kurt Weitzmann's notion that 'the classical heritage could be made to harmonize with the Christian tradition, and both could give birth to a unified style'. ${ }^{3}$ In more recent years, fresh insights in the same direction have been drawn from the study of late ancient literary (chiefly poetic) communication: deeply rooted in the historical and social context, it was inspired by an ideological agenda of confrontation and dialogue with pagan culture, in which classical paideia was essential to the self-definition of the educated élite, ${ }^{4}$ and was viewed as a pervasive language of mutual understanding, 'un langage pour instaurer un dialogue'. 5 The case of Nonnus of Panopolis (fl. fifth century), the author of both the bulkiest pagan poem of the ancient world and the most widespread paraphrase of a Gospel, is particularly important in this context. ${ }^{6}$

Perhaps one of the most indicative moments in this process is the well-known decree of Emperor Julian in 362 (Codex Theodosianus XIII.3.15), which forced Christian professors to withdraw from the teaching of pagan subjects and doctrine, intimating that Hellenic paideia should not be mixed with Christian belief and starting from the assumption that the acceptance of hellenismos in linguistic (and literary) terms ${ }^{7}$ could not be separated from hellenismos in terms of moral values and religion, for 'I find it absurd that those who explain [the ancient authors'] works, should look down upon the gods they worshipped. ${ }^{8}$

This measure, which did not survive its author and was deleted in January 364, has been the object of much historiographical revision, and it probably did not really

\footnotetext{
2 G. Bowersock, Hellenism in Late Antiquity, Michigan, 1990; L. Török, Transfigurations of Hellenism: Aspects of Late Antique Art in Egypt AD 250-700, Leiden and Boston, 2005.

3 K. Weitzmann, Greek Mythology in Byzantine Art, Princeton, 1951, p. 4.

4 A. Cameron, 'Poets and Pagans in Byzantine Egypt', in Egypt in the Byzantine World 300-700, ed. R. Bagnall, Cambridge, 2007, pp. 21-46 (29).

${ }^{5}$ G. Agosti, 'Usurper, imiter, communiquer: le dialogue interculturel dans la poésie grecque chrétienne de l'Antiquité tardive', in L'oiseau et le poisson, ed. N. Belayche and J.-D. Dubois, Paris, 2011, pp. 27599, esp. 293 and 277.

${ }^{6}$ See, most recently, R. Shorrock, The Myth of Paganism, London, 2011, on the cultural meaning of the identification between Dionysus and Christ, on which see also Cameron, 'Poets and Pagans' (n. 4 above), p. 37; P. Chuvin, 'Revisiting Old Problems: Literature and Religion in the Dionysiaca', in Nonnus of Panopolis in Context, ed. K. Spanoudakis, Berlin and New York, 2014, pp. 3-18.

7 See L. Pagani, 'Language Correctness (Hellenismos) and its Criteria', in Brill's Companion to Ancient Greek Scholarship, ed. F. Montanari, S. Matthaios and A. Rengakos, Leiden 2015, pp. 798-848. On the relationship with Homer and poetry, see F. Pontani, 'Ex Homero grammatica', in Ancient Scholarship and Grammar, ed. S. Matthaios, F. Montanari and A. Rengakos, Berlin and New York, 2011, pp. 87-103.

8 Julian, Oeuvres complètes, ed. J. Bidez, $3^{\text {rd }}$ ed., I.2, Paris, 1972, 61.422a-424b (this is no. 36 in Julian, Letters. Epigrams. Against the Galilaeans. Fragments, transl. and ed. W. C. Wright, Cambridge MA,

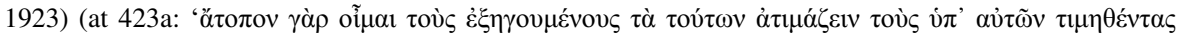

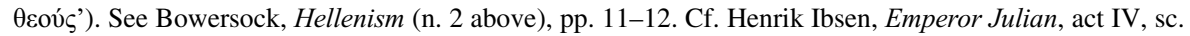
2: 'Henceforth you will no longer be allowed to interpret our ancient poets and philosophers, for I regard it as unreasonable to let you suck knowledge and skill from sources in the truth of which you do not in the least believe.'
} 
entail all the implications ascribed to it by Christian polemists and historians. ${ }^{9}$ However, the Christian perspective is still very significant in assessing the event: Gregory of Nazianzus's (c. 325-389) famous speech against Julian (Oration 4) focuses precisely on the appropriation and use of the adjective "E $\lambda \lambda \eta \nu / E \lambda \lambda \eta v \iota \kappa o$, and insists that the Apostate's hostility against the Christians proceeded from a tendentious reading of this term as referring to religion rather than to a linguistic, literary and cultural heritage:

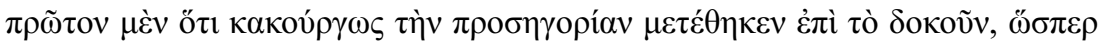

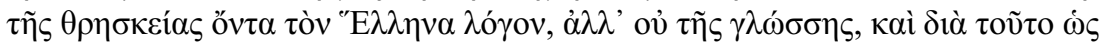

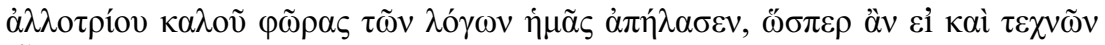

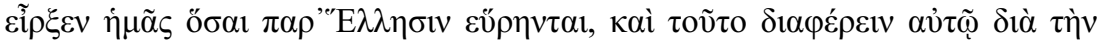
ó $\omega \omega v v \mu i ́ \alpha v$ Ẻvó $\mu 1 \sigma \varepsilon v$.

[Julian has wickedly transformed the meaning of 'Greek' so as to represent a religion but not a language, and accordingly, as if we had stolen someone else's goods, he has stripped us of our speech (logoi). Just as if he were to keep us from whatever arts the Greeks had devised, he thought that in this matter of language he could make it exclusively his concern because of the use of the same term. $]^{10}$

The implication of Gregory's statement is clear: classical culture had to be assimilated rather than countered or 'replaced' by a different set of texts and artworks, and it could remain harmless (or even beneficial) provided a sound Christian faith established itself in the readers' souls. ${ }^{11}$ This response to the 'challenge of Homer' is most familiar today to readers of Basil's protreptic Address to the Young, of John Chrysostom's homilies and of Clement of Alexandria's Stromateis. ${ }^{12}$ Gregory himself, with his unparalleled output of 17,000 lines in classicizing verse devoted to Christian issues, is a good paradigm of this ideology of appropriation: he deliberately wanted to stand out as the most important Christian poet 'in classical fashion', to pursue the Hellenistic tradition by simultaneously displaying his different religious outlook and to provide reference works for young

\footnotetext{
9 A. Kaldellis, Hellenism in Byzantium, Cambridge, 2007, pp. 146-54. K. O. Sandnes, The Gospel 'According to Homer and Virgil', Leiden and Boston, 2011, pp. 84-97, gives an overview of the evidence. See also K. O. Sandnes, The Challenge of Homer, London, 2009, pp. 160-72.

${ }^{10}$ Gregory of Nazianzus, Discours 4-5. Contre Julien, transl. and ed. J. Bernardi, Paris, 1983, IV.5. Translation from Bowersock, Hellenism (n. 2 above), pp. 11-12 (adapted).

11 See also Gregory of Nazianzus, Discours 42-43, transl. and ed. J. Bernardi, Paris, 1992, 43.21; H.-G. Nesselrath, 'Die Christen und die heidnische Bildung', in Leitbilder der Spätantike, ed. J. Dummer and M. Vielberg, Stuttgart, 1999, pp. 79-100 (92-5); K. Demoen, 'The Attitude towards Greek Poetry in the Verse of Gregory Nazianzen', in Early Christian Poetry, ed. J. den Boeft and A. Hilhorst, Leiden, 1993, pp. 235-52 (252); Kaldellis, Hellenism (n. 9 above), pp. 158-63, on Gregory's approach.

12 Sandnes, Challenge (n. 9 above); id., Gospel (n. 9 above), pp. 65-84; Nesselrath, 'Die Christen' (n. 11 above), pp. 87-9; A. Cameron, Christianity and the Rhetoric of Empire, Berkeley, 1991; ead., 'Education and Literary Culture', in The Cambridge Ancient History, XIII, Cambridge, 1998, pp. 665-706 (667-79); L. Miguélez-Cavero, Poems in Context: Greek Poems in the Egyptian Thebaid: 200-600 AD, Berlin and New York, 2008, pp. 191-6 and 209-10.
} 
Christians by raising to the highest level the process of 'conversion' of ancient poetic formulas or artistic customs. ${ }^{13}$

In response to Julian's provocation, a somewhat different path was followed by the shadowy figures of the two Apollinarioi, who allegedly rewrote in verse (or in high-brow literary prose) several important texts of the Christian tradition, starting from a verse paraphrase of the Pentateuch in Greek hexameters, intended to ennoble the wording of the Holy Scripture and to present the faithful with a literary model that might be both stylistically and inherently acceptable:

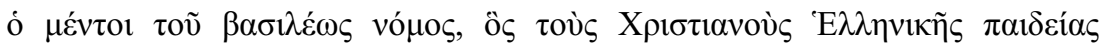

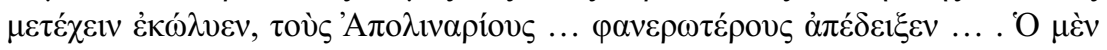

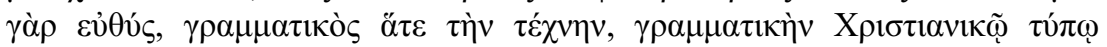

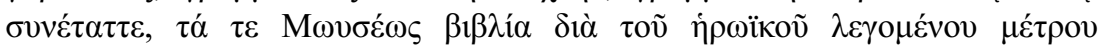

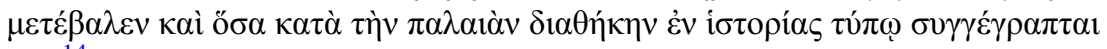
${ }^{14}{ }^{14}$

[The law of the emperor forbidding Christians to take part in pagan education made the Apollinarioi more illustrious ... . One of them, being a grammarian, immediately composed a grammar in Christian fashion and transposed into the so-called 'heroic' metre all the books of Moses and those which, in the Old Testament, are written in the genre of history .... . ]

This passage of Socrates Scholasticus (c. 380-450) has been the object of various analyses, from those which regard it as a reliable witness to the evolution of Christian teaching, ${ }^{15}$ to the conspicuously sceptical argument of Paul Speck, who ventured the idea that the works of the Apollinarioi not only did not survive Julian's age - as Socrates himself tells us - but, in fact, never existed at all, and that Socrates's main aim was to cast a negative light on any attempt of this kind. ${ }^{16}$ Sozomen's (c. 380-440) parallel account (Ecclesiastical History, V.18.3-4) describes the Apollinarioi's poetic reaction to Julian's edict as twenty-four books

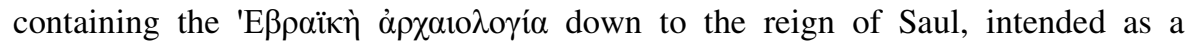
substitute for the Homeric poems. Sozomen stresses that those authors created in a

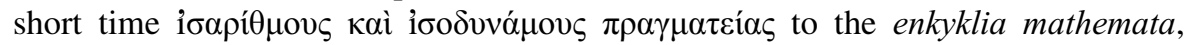
deserving high praise for this accomplishment and ensuring plausible textbooks for introducing pupils to higher studies. Alan Cameron has also expressed doubts about

\footnotetext{
13 See the excellent overview by C. Simelidis, Selected Poems of Gregory of Nazianzus, Göttingen, 2009, pp. 30-46; Cameron, 'Poets and Pagans' (n. 4 above), pp. 30-31; Cameron, 'Poetry' (n. 1 above), p. 347; Demoen, 'The Attitude' (n. 11 above), also stressing the contradictions in Gregory's oeuvre; Agosti, 'Greek Poetry' (n. 1 above), p. 366; J. A. McGuckin, 'Gregory: The Rhetorician as Poet', in Gregory of Nazianzus: Images and Reflections, ed. J. Børtnes and T. Hägg, Copenhagen, 2006, pp. 193-212.

14 Socrates, Historia Ecclesiastica, ed. G. C. Hansen, Berlin, 1995, III.16.1 and III.16.3.

15 C. Markschies, 'Lehrer, Schüler, Schule', in Religiöse Vereine in der römischen Antike, ed. U. Egelhaaf-Gaiser and A. Schäfer, Tübingen, 2012, pp. 97-120 (109-10); Nesselrath, 'Die Christen' (n. 11 above), pp. 84-8; Cecconi, 'Contenuti religiosi' (n. 1 above), pp. 234-5.

${ }^{16}$ P. Speck, 'Sokrates Scholastikos über die beiden Apollinarioi', Philologus, 141, 1997, pp. 362-9. See Sandnes, Gospel (n. 9 above), pp. 97-105, stressing that the Apollinarioi also used other metres, 'so that no form of the Greek language remained unfamiliar to the Christians' (p. 98). For a sober discussion, see Simelidis, Selected Poems (n. 13 above), pp. 24-6.
} 
the reliability of this account, and Gianfranco Agosti even believes that it was invented wholesale in the intellectual milieux of Constantinople during the fifth century. $^{17}$

Whatever the historical truth, what interests us here is the literary construction: the genre of poetic paraphrase was conceived of and presented as a response to the Apostate's 'stealing' of Hellenic culture from the hands of the Christians who, on their side, were getting increasingly used to exploiting it in the framework of their own artistic production; this is, as Socrates puts it in disparaging terms, the straightforward idea of using the opponents' weapons. In reality, the tradition of a new Christian poetry in classical metre and style arose in Egypt precisely in the mid-fourth century: ${ }^{18}$ the very fact that language, metre and style were overtly inherited and acquired from ancient prototypes, entailed that the idea of 'Hellenism' had substantially boiled down to formal issues (as Julian acutely sensed), so that little serious opposition could come from the Christian milieu. ${ }^{19}$ It is this cultural framework which prompted Alan Cameron to conclude that:

mythological art and poetry helped many educated people to embrace a Christianity that did not involve rejecting too much of the past. Not the least important aspect of the relations between poet and community in late antiquity is that, by keeping alive the forms and motifs of classicizing poetry, and above all by reviving mythological epic, they eased the transition from Hellenism to Christianity. ${ }^{20}$

No matter what we make of the Apollinarioi, the most obvious venue for this encounter of Christian content and pagan form was poetic paraphrases and centos: I am referring here to the works by fourth- and fifth-century Greek and Latin authors such as Iuvencus, Sedulius, Nonnus, Proba, Eudocia, but also (and earlier) the Codex Visionum. ${ }^{21}$ The recent surge in the study of these genres has rehabilitated texts which had long been disqualified as boring tours de force or aestheticizing divertissements, turning them into full-fledged exegetical acts aiming to accomplish a sort of translatio from the classical to the Christian camp, not by way of opposition but through a sort of contamination. ${ }^{22}$ The most evident phenomenon in

\footnotetext{
17 G. Agosti, 'L'epica biblica greca nell'età tardoantica', in La Scrittura infinita, ed. F. Stella, Florence, 2001, pp. 67-104 (85-93); Cameron, 'Poets and Pagans' (n. 4 above), pp. 29-30; Sandnes, Gospel (n. 9 above), pp. 103-5.

18 Agosti, 'Usurper' (n. 5 above), pp. 277-8; Agosti, 'Cristianizzazione' (n. 1 above), pp. 195-9; Cameron, 'Poetry' (n. 1 above).

19 One might cite Nilus of Ancyra's epistle II.49 (available in Patrologia Graeca, ed. J.-P. Migne,

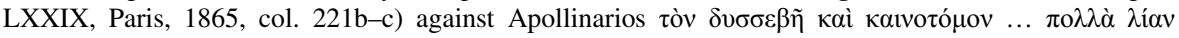

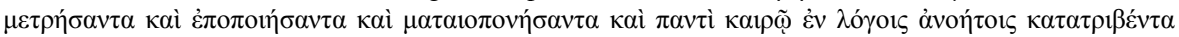
('the impious innovator ... who wrote so much in metre, in epic fashion and in his vain style, being constantly versed in absurd writings'); but it is by no means a mainstream attitude: see Simelidis, Selected Poems (n. 13 above), pp. 27-9.

20 Cameron, 'Poets and Pagans' (n. 4 above), p. 39.

21 On the genre of paraphrase in late antiquity see Miguélez-Cavero, Poems in Context (n. 12 above), pp. 309-16. See also R. Green, Latin Epics of the New Testament, Oxford, 2006; Agosti, 'Cristianizzazione' (n. 1 above), pp. 202-3.

22 Agosti, 'Greek Poetry' (n. 1 above), p. 372.
} 
this respect (attested even beyond the narrow boundaries of these genres) is the proliferation of pagan vocabulary and elements in the verse devoted to the life of Christ or to other religious issues or dogmas. Modern categorizations of these poetic devices have taken into account:

a) their varying degree of importance, from the simple adoption of a single pagan epithet for Christ (or God, or the Virgin Mary: German technical jargon calls this Usurpation), down to a wider network of allusion to (or rewriting of) a specific episode of Virgil or Homer within a Christian poem (what the Germans call Kontrastimitation); ${ }^{23}$

b) their different poetical approach to classical texts, that is, the 'Egyptian' line of Nonnus (with its 'poetics of paradox' and a pronounced syntactic, lexical and even metrical originality), as opposed to the 'Constantinopolitan' line, with its more distinctly Homeric option (the centos and the Psalter Metaphrasis falsely ascribed to Apollinarios). ${ }^{24}$

Typical examples are, for instance, the ubiquitous use of Mount Olympus for heaven or Hades for hell, the re-functionalization of the prayer pattern (Prudentius's Psychomachia 1: 'Christe, graves hominum semper miserate labores' is imported wholesale from Virgil's Aeneid VI.56 to Apollo, with Christe replacing Phoebe), or the allusion to Dido's hunting horse when referring to Jesus's donkey in his entrance to Jerusalem. ${ }^{25}$

Centos and paraphrases, for all their differences, had the twofold ambition of fashioning Christian narratives in pagan dress (thus stimulating an implicit synkrisis between two distinct and, indeed, competing canonical traditions), and of answering the need for an aesthetically plausible substitute which might rival the masterpieces of ancient literature and serve the purpose of day-by-day instruction of pupils. These works were addressed not only to Christian readers needing to be trained in linguistic skills and to be artistically corroborated in their belief, but also to pagan readers expecting to be convinced, in both aesthetic and religious terms, by a radically new literary genre: the two sides of the coin were not mutually exclusive. ${ }^{26}$ This is not to argue, of course, the old thesis that paraphrases, ekphraseis and centos served above all didactic purposes: several of them also entailed a high-brow exegetical purport, as recent commentaries abundantly show, and were designed to foster a genuine interaction between pagan and Christian culture in the mind of readers capable of spotting the allusions and of interpreting such impervious texts. ${ }^{27}$

The example of Nonnus is particularly revealing: the readership of his Paraphrase and of other similar and contemporary poems must have been a mixed

\footnotetext{
23 P. W. A. T. van der Laan, 'Imitation créative dans le Carmen Paschale de Sedulius', in Early Christian Poetry, ed. J. den Boeft and A. Hilhorst, Leiden, 1993, pp. 135-66; K. Thraede, 'Epos', Reallexikon für Antike und Christentum, ed. E. Dassmann et al., V, Stuttgart, 1962, pp. 983-1042 (1034-42); Nonnus of Panopolis, Parafrasi del Vangelo di San Giovanni. Canto V, ed. G. Agosti, Florence, 2003, pp. 89-92.

24 Nonnus of Panopolis, Parafrasi, ed. Agosti, (n. 23 above), pp. 100-102.

25 See H. Hagendahl, Latin Fathers and the Classics, Göteborg, 1958, pp. 382-95; van der Laan, 'Imitation créative' (n. 23 above), pp. 150-64.

26 Agosti, 'Greek Poetry' (n. 1 above), pp. 378-80.

27 See Agosti, 'Usurper' (n. 5 above), pp. 283-4; Agosti, 'Cristianizzazione' (n. 1 above), pp. 199-200 and 204-10; id., 'L'epica' (n. 17 above), pp. 68-73.
} 
one, mainly Christian but also partly pagan, educated according to the ancient paideia and thus capable of recognizing Nonnus's deft allusions and sophisticated textual strategies. ${ }^{28}$ The anonymous author of the Metaphrasis of the Psalms (Pseudo-Apollinarios), in his turn, overtly invites pagan readers, the so-called ô $\lambda \lambda$ or (Prooemium 32), to apprehend and believe the new message of David and Christ; ${ }^{29}$ and John Zonaras (fl. 12th century) informs us that his Metaphrasis was read in schools along with Gregory's verse 'so that the young may study them instead of the Hellenic doctrines and thus refine their Greek and learn the metre'. ${ }^{30}$

That pupils or advanced students also read these works is most likely: the poems of Dioskoros of Aphrodito (c. 520-585) show that Nonnus's Paraphrase, at least in Egypt, 'faisait partie des classiques étudiés à l'école'. ${ }^{1}$ That Gregory of Nazianzus's verse synopses of the Old and New Testament were read in the classroom is confirmed by their manuscript and exegetical tradition. ${ }^{32}$ And it may thus come as no wonder that, at least in Socrates's literary construction (see above), the first Apollinarios, the one who allegedly wrote the paraphrase of the Pentateuch, was also a grammarian, and that - we are told - he was the first to write a grammar

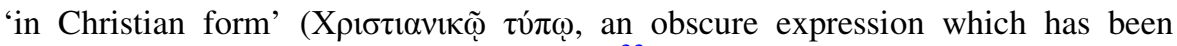
variously explained by modern interpreters). ${ }^{33}$ Let us keep this in mind as we turn to the next section.

\section{Hellenic Prototypes and Christian Poetry: From Byzantium to Early Italian Humanism}

One of the main difficulties in the Nachleben of classical Vorlagen in the history of Christian poetry was represented by pagan mythology and the related cultic practices. While single terms (especially nouns or epithets) could be easily accommodated in the new cultural and religious context, the same did not hold for the bulk of often licentious narratives involving gods and goddesses: this material either had to be read allegorically or simply left out from pious writings, as the

\footnotetext{
28 Nonnus of Panopolis, Parafrasi, ed. Agosti (n. 23 above), pp. 95-102.

29 Agosti, 'L'epica' (n. 17 above), pp. 87-9; A. Faulkner, 'Faith and Fidelity in Biblical Epic', in Nonnus of Panopolis in Context, ed. K. Spanoudakis, Berlin and New York, 2014, pp. 195-210, with earlier bibliography.

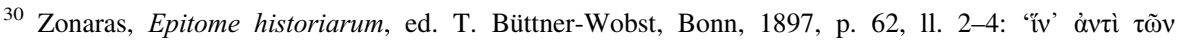

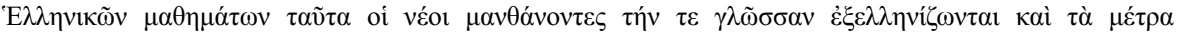

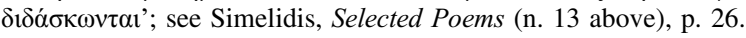

31 G. Agosti, 'Niveaux de style, littérarité, poétiques', in «Doux remède...» Poésie et poétique à Byzance, ed. P. Odorico, Paris, 2009, pp. 99-119 (113).

32 See Simelidis, Selected Poems (n. 13 above), pp. 77-9. It should be further noted that a set of mythographical scholia to Gregory of Nazianzus's Oration 4 (and 5, 39 and 43) have been (wrongly) attributed to Nonnus of Panopolis: see Pseudo-Nonniani in IV orationes Gr. Nazianzeni commentarii, ed. J. Nimmo Smith, Turnhout, 1992, esp. p. 8.

33 'Ein Schulbuch der Grammatik mit ausschließlich christlichen (biblischen?) Beispielen', according to Speck, 'Sokrates' (n. 16 above), p. 364; 'a book which included how Christians could cope with Greek literature', for Sandnes, Gospel (n. 9 above), p. 100, n. 111.
} 
metaphor of the Christians acting like 'bees' (featuring already in Basil) explicitly suggests. $^{34}$

The survival of pagan imagery throughout the Middle Ages followed different paths in both East and West. After the age of Justinian, ${ }^{35}$ Byzantine culture, with its strong accent on the direct knowledge of (some) pagan texts in the education of élites, did continue to embrace references to classical prototypes in its artistic and literary output; but these symptoms of Hellenism, however important, remained mostly limited to the level of form, without any real ambition or plan to revive the ancient world or to revamp its deeper tenets. ${ }^{36}$ The Hellenic heritage had to be basically confined in a corner from which it could not seriously aspire to an active role in the shaping of contemporary thought: its opheleia / utilitas had to lie elsewhere; ${ }^{37}$ by renouncing, or denouncing, Hellenism as a system of thought, they [i.e., the Byzantines] were able to preserve and even proclaim Hellenism as a mode of expression'. ${ }^{38}$ Anthony Kaldellis's studies, in particular, have illuminated the paths and shapes of this controversial appropriation, and the debate on the concept of 'Byzantine humanisms' or 'Byzantine renaissances' has also put this issue in the right critical perspective. ${ }^{39}$

In the realm of poetry proper - which is my main focus here - Byzantine versification followed a widely diverging path from its ancient counterpart: it preferred the metrical structures of the liturgical hymn or the ubiquitous dodecasyllable (an evolution of the iambic trimeter), ${ }^{40}$ and structured its own discourse around the 'totalizing discourse' of Christian rhetoric. ${ }^{41}$ Experiments in the more difficult ancient metres (starting with the hexameter) were not common, and they still await to be collected and studied systematically in this perspective. ${ }^{42}$ Of course, there were exceptions: John Geometres in the tenth century is indebted to

\footnotetext{
34 Kaldellis, Hellenism (n. 9 above), p. 163; H. Rahner, Greek Myths and Christian Mystery, New York, 1963; Griechische Mythologie und frühes Christentum, ed. R. von Haehling, Darmstadt, 2005; W. Liebeschuetz, 'Pagan Mythology in the Christian Empire', International Journal of the Classical Tradition, 2, 1995, pp. 193-208.

35 On this turning-point, see F. Pontani, 'Scholarship in the Byzantine Empire', in Brill's Companion to Ancient Greek Scholarship (n. 7 above), pp. 298-300, with further bibliography.

36 A. Kaldellis, 'Classical Scholarship in Twelfth-Century Byzantium', in Medieval Greek Commentaries on the Nicomachean Ethics, ed. C. Barber and D. Jenkins, Leiden and Boston, 2009, pp. 1-40 (1-7); P. Agapitos, 'Teachers, Pupils and Imperial Power in Eleventh-Century Byzantium', in Pedagogy and Power, ed. N. Livingstone and Y. L. Too, Cambridge and New York, 1998, pp. 170-91 (171-4); Pontani, 'Scholarship' (n. 35 above), pp. 301-2, with updated bibliography.

37 On opheleia, see, e.g., Sandnes, Challenge (n. 9 above), pp. 218-30; L. Bossina, 'La chiesa bizantina e la tradizione classica', Humanitas, 58, 2003, pp. 64-84.

38 P. Magdalino, 'Hellenism and Nationalism in Byzantium', in id., Tradition and Transformation in Medieval Byzantium, London, 1991, pp. 1-29 (11), with special reference to the Comnenian age.

39 W. Treadgold, 'The Macedonian Renaissance', in Renaissances before the Renaissance, Stanford, 1984, pp. 75-98; id., The Byzantine Revival, Stanford, 1988.

40 M. Lauxtermann, Byzantine Poetry from Pisides to Geometres, Vienna, 2003; id., 'La poesia', in Lo spazio letterario del Medioevo, ed. G. Cavallo and G. de Gregorio, III.1, Rome, 2004, pp. 301-43.

41 A. Cameron, Christianity and the Rhetoric (n. 12 above).

42 Agosti, 'L'epica' (n. 17 above), 100-102.
} 
Homer, Gregory of Nazianzus and perhaps Nonnus ${ }^{43}$ in the Comnenian age, John Tzetzes wrote his Carmina Iliaca in hexameters; ${ }^{44}$ one century later, the learned monk Maximus Planudes was capable of composing suo Marte hexameters emulating the Phaenomena of Aratus, as well as epigrams or idylls in hexametrical form. $^{45}$

But these exceptions never became a system. Let us take an example: the genre of epigrams was popular both in ancient and in Byzantine times, and the anthologies through which so many texts of all the ages of Hellenic literature came down to us were assembled by two monks, Constantine Cephalas in the tenth century and Maximus Planudes in the late thirteenth. Cephalas, when introducing Strato's sylloge of paederotic epigrams, remarked that the author conceived these texts 'taking personal delight in the diction of epigrams, not in their meaning' ${ }^{46}$ During the Palaeologan 'renaissance', such a deep connoisseur of pagan literature as Planudes penned a note on the second to last page of his famous anthology (obviously replete with morally dubious pieces, for all his censorship or bowdlerization of the most uncomfortable texts), ${ }^{47}$ giving explicit praise not to any of the ancient epigrammatists, but rather to Nonnus's Paraphrase of St John's Gospel, which opened the codex:

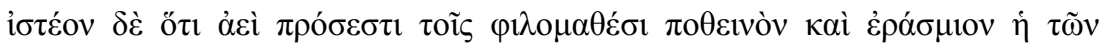

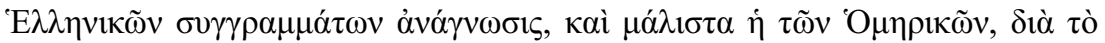

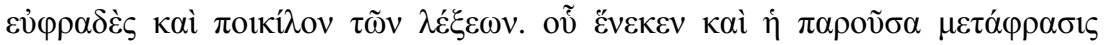

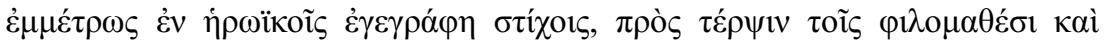

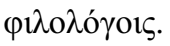

[One should note that the reading of Hellenic literature has always been an object of longing and delight for lovers of learning, and particularly the reading of the poems of Homer, because of the grace and variety of the language. That is why the present metrical paraphrase has been written in heroic metre, to give pleasure to lovers of learning and literature.] ${ }^{48}$

\footnotetext{
${ }^{43}$ E. M. van Opstall, Jean Géomètre. Poèmes en hexamètres et en distiques élégiaques, Leiden and Boston, 2008; ead., 'Poésie, rhétorique et mémoire littéraire chez Jean Géomètre', in «Doux remède...» (n. 31 above), p. 229-44.

44 See M. Cardin, 'Teaching Homer through (Annotated) Poetry: John Tzetzes' Carmina Iliaca', in Brill's Companion to Prequels, Sequels and Retellings of Classical Epic, ed. R. Simms, Leiden-Boston 2018, pp. 90-114.

45 J. Martin, Histoire du texte des Phénomènes d'Aratos, Paris, 1956, pp. 295-9; F. Pontani, 'The World on a Fingernail', Traditio, 65, 2010, pp. 77-100; id., 'Esametri nonniani e mappae mundi', in Intorno al papiro di Artemidoro, ed. C. Gallazzi and B. Kramer, II, Milan, 2012, pp. 197-217; Maximus Planudes, Idyllium, ed. F. M. Pontani, Padua, 1973. See now, I. Taxidis, Les épigrammes de Maxime Planude, ed. I. Taxidis, Berlin and Boston, 2017.

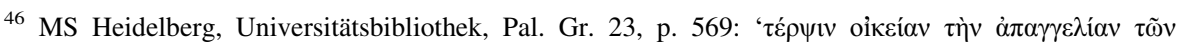

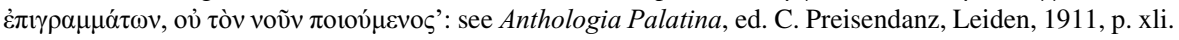
47 G. A. Karla, 'Dr. Bowdler in Byzanz?', Classica et Mediaevalia, 57, 2006, pp. 213-38; F. Valerio, 'Planudeum', Jahrbuch der Österreichischen Byzantinistik, 61, 2011, pp. 229-36.

48 MS Venice, Biblioteca Marciana, Marc. Gr. 481, fol. $122^{\mathrm{v}}$; translation from R. Browning, 'Tradition and Originality in Literary Criticism and Scholarship', in Originality in Byzantine Literature, Art and Music, ed. A. R. Littlewood, Oxford, 1995, pp. 17-28 (21); Pontani, 'Scholarship' (n. 35 above), p. 414.
} 
Planudes thus reasserted the idea that traditional form was suitable to ennoble Christian content and to make it more appealing to the ears of the learned; the classical heritage provided, as it were, a good mould for bringing about terpsis in the philomatheis. The one poetical text of the Byzantine millennium in which stylistic and lexical choices achieved a true effect of cultural Verfremdung and interference is the dramatic text known as Christus patiens: it is no coincidence that this long cento narrating the Passion of Christ by means of Hellenic tragic and iambic poetry, although certainly produced in the twelfth century, has been dated by several scholars to late antiquity and attributed by many - though wrongly - to the pen of Gregory of Nazianzus. ${ }^{49}$

The 'survival of the pagan gods' through the Latin Middle Ages has been the object of much debate ever since the publication of Jean Seznec's important book, which envisaged a perspective of continuity rather than discontinuity; ${ }^{50}$ the remarks of (among others) Erwin Panofsky and Eugenio Garin have since distinguished more neatly between different modes of 'survival', especially as far as poetry is concerned, and have nuanced Seznec's optimism by appealing to different, less optimistic views of the classical heritage. ${ }^{51}$ I shall not deal here with such a wideranging and delicate issue, all the more so as the perception of Hellenism proper in the West was largely indirect, given that the ability to read Greek texts in the original is hardly attested before the late fourteenth century in Florence.

Late fourteenth-century Florence is a nice place to investigate, though. In those years, Giovanni Boccaccio's (1313-1375) Genealogiae deorum gentilium, perhaps the first work of this sort where Greek sources started to be exploited in the original, became a paramount text for the rehabilitation of poetry as a discipline no less important than philosophy in the study of the classical heritage. Poets were regarded as the heralds of a 'poetic theology' under whose outer layer hidden senses could be detected; recent research has shed new light on the ways in which Boccaccio inherited the medieval understanding of myth but also started to consider it in connection with its poetical (and thus deeply human) construction, thereby fleshing out the foundations for allegorical reading. ${ }^{52}$

A similar faith in poetry also featured at the beginning of Coluccio Salutati's (1331-1406) De laboribus Herculis, with the piety and moral value of ancient poetic fables expressly praised, no less than the role of moral exhortation and positive exemplum of ancient literature (as opposed to pagan philosophy and its dangerous

\footnotetext{
49 See N. Vakonakis, Das griechische Drama auf dem Weg nach Byzanz, Tübingen, 2011, pp. 97-104; W. Hörandner, 'Lexikalische Beobachtungen zum Christos paschon', in Studien zur byzantinischen Lexikographie, ed. E. Trapp, Vienna, 1988, pp. 183-202; F. Pontani, 'Homer, the Bible and Beyond', Classical Quarterly, 56, 2006, pp. 661-4. For the attribution, see Gregory of Nazianzus, La Passion du Christ, ed. A. Tuilier, Paris, 1969; F. Trisoglio, San Gregorio di Nazianzo e il Christus patiens, Florence, 1996.

50 J. Seznec, The Survival of the Pagan Gods, Princeton, 1972.

51 See A. Buck, L'eredità classica nelle letterature neolatine del Rinascimento, Brescia, 1990, pp. 24769; E. Panofsky, Studies in Iconology, New York, 1939; E. Garin, 'Le favole antiche', in id., Medioevo e Rinascimento, Bari, 1963, pp. 66-89. See also D. C. Allen, Mysteriously Meant, Baltimore, 1970.

52 Garin, 'Favole antiche' (n. 51 above), p. 73; D. Lummus, 'Boccaccio's Poetic Anthropology', Speculum, 87, 2012, pp. 724-65.
} 
nature). ${ }^{53}$ In the very last years of the fourteenth century, however, the same Coluccio Salutati opened his De fato with an overt rebuttal of the habit of invoking the pagan gods in vain (precisely the issue of Usurpation I touched on in the previous section):

Cum tamen et Iunonem et alios paganorum deos suis inserere confabulationibus et litteris non recusent, nec gentilia per illos deos scribere iuramenta, ut 'medius fidius', 'edepol', 'castor', 'hercle' et his similia - quod quidem est longe irreligiosius - vereantur. ${ }^{54}$

[For they do not refrain from inserting in their speech and writings Juno and other pagan deities, nor are they afraid to take pagan oaths in the name of those gods, like medius fidius, edepol, castor, hercle and the like - which is by far even more sacrilegious.]

And in the very first years of the fifteenth century, disparaging attitudes towards both classical studies and poetry in classical fashion were championed by the important Florentine intellectual Giovanni Dominici (1356-1419) in his Lucula noctis - a treatise expressly devoted to the issue 'an fidelibus Christianis licitum sit litteris secularibus uti'. Dominici, following the patristic tradition, wished to subordinate pagan disciplines to Christian wisdom and to employ allegory for the interpretation of morally dubious poetry; in particular, he showed the utmost disregard for Usurpation:

E che peggio è, quella teneruccia mente si riempie del modo del sacrificio fatto agli falsi iddii, prima diventando pagani che cristiani, e prima chiamando dio Juppiter o Saturno, Venus o Cibeles, che il sommo Padre, Figliuolo e Spirito santo. $^{55}$

[And - worse still - their tender mind is filled with the practice of sacrifice to the false gods, so that people more readily become pagans than Christians and invoke as gods Jupiter, Saturn, Venus and Cybele rather than the Father, the Son and the Holy Spirit.]

Interestingly, when it comes to recommending Latin poetry, Dominici singles out (along with Boethius, Petrarch and Dante) some authors of Latin biblical paraphrases:

Si delectat poetas legere ... propter dulcedinem metri et eloquii venustatem ..., legantur primo Torquatus, buccolicum Petrarche Dantisve, Prudentii, Sedulii, Aratoris, Iuvenci. ${ }^{56}$

\footnotetext{
53 Coluccio Salutati, De laboribus Herculis, ed. B. L. Ullman, Padua, 1951. For a different, less favourable, verdict on pagan virtues as opposed to Christian faith, see R. G. Witt's introduction to Coluccio Salutati, On the World and Religious Life, Cambridge MA and London, 2014, pp. xiii-xiv.

54 Coluccio Salutati, De fato et fortuna, ed. C. Bianca, Florence, 1985, proemium, 11. 12-16.

55 Giovanni Dominici, Regola del governo di cura familiare, ed. D. Salvi, Florence, 1860, p. 135.

56 Lucula noctis XLV.133-7. See C. Mésonnat, Poetica Theologica. La 'Lucula Noctis' di Giovanni Dominici e le dispute letterarie tra '300 e '400, Rome, 1984.
} 
[If you wish to enjoy the reading of poetry ... because of the sweetness of metre and the beauty of style ..., read first of all Torquatus, the bucolic poetry of Petrarch or Dante, Prudentius, Sedulius, Arator, Iuvencus.]

Decades later, Dominici's line of stern rejection of anything ancient was taken up and deepened by Girolamo Savonarola (1452-1498). ${ }^{57}$ Following Garin, if the dilemma between pagan and Christian poetry was indeed very common, the discrimen between a 'medieval' and a 'humanist' attitude ran along the distinction between, on the one hand, the mere adoption of forms and the exterior admiration of beauty (this is still, by and large, Boccaccio's stance) and, on the other, the attribution to the ancient masterpieces of a particular dignity together with a special quality and excellence in uncovering the full substance of being. ${ }^{58}$

The use of myth as a pure stylistic adornment and - again - of the names of the gods in a neutral, metonymic sense such as that envisaged as early as Cicero, ${ }^{59}$ may have been regarded as potentially dangerous in an age when pagan philosophies were coming back into fashion and Platonic thought, for instance, was starting to permeate the Florentine élite. An extreme example, in the second half of the fifteenth century, was Michael Marullus (d. 1500), whose Natural Hymns, dedicated to several ancient gods, ${ }^{60}$ reproduce ancient poetic forms not only in terms of metre and style, but also by way of a real revival of attributes, cultic features and competences of the single deities. ${ }^{61}$ No one thinks today that Marullus seriously wished to restore paganism (although there are still many doubts about his Greek counterpart, Gemistus Pletho), ${ }^{62}$ but his contact with the background of Hellenic mythology, and with the tenets of Neoplatonic philosophy, turn his verse into a sort of mystical and poetic vehicle travelling towards an autonomous and idiosyncratic interpretation of nature. ${ }^{63}$

Even without resorting to the exceptional case of Marullus, the possibility of writing classical Latin verse on Christian subjects was hotly debated by Italian humanists. Francesco Bausi has devoted a long essay to the two main approaches followed by Christian poets in the latter part of the fifteenth century and in the early

\footnotetext{
57 Ugolino Verino, Epigrammi, ed. F. Bausi, Messina, 1998, p. 67.

58 Garin, 'Favole antiche' (n. 51 above), p. 71.

59 See De oratore III.167; De natura deorum II.60 with Pease ad loc. (II, Cambridge MA, 1958, p. 691).

60 Including the Sun, in the wake of Julian the Apostate's Oration on the Sovereign Sun; see P. Chuvin, Cronaca degli ultimi pagani, Brescia, 2012, pp. 197-205.

61 See Michael Marullus - ein Grieche als Renaissancedichter in Italien, ed. E. Lefèvre and E. Schäfer, Tübingen, 2008; K. A. E. Enenkel, 'Todessehnsucht am Schwarzen Meer: Michael Marules' lyrische Autobiographik im "Exilgedicht" ("De exilio suo"; 1489/90; 1497) und anderen Gedichten', in Die Erfindung des Menschen: Die Autobiographik des frühneuzeitlichen Humanismus von Petrarca bis Lipsius, Berlin and New York, 2008, pp. 368-428.

62 N. Siniossoglou, Radical Platonism in Byzantium, Cambridge, 2011.

63 Michael Marullus, Inni naturali, transl. D. Coppini, Florence, 1995; id., Hymnes naturels, transl. J. Chomarat, Geneva, 1995; id., 'Hymni naturales'. Hymnen an die Natur. Erste deutsche Gesamtübersetzung, transl. Otto Schönberger, Würzburg, 1996. See also W. Ludwig, Antike Götter und christlicher Glaube: Die Hymni Naturales von Marullo, Hamburg, 1992.
} 
sixteenth. ${ }^{64}$ I refer to the more distinctly 'classicizing' line of Girolamo Vida (14851566), Iacopo Sannazaro (1458-1530) and Battista Spagnoli (1447-1516), in which characters and truths of the Christian faith are often verbally disguised in pagan dress, ${ }^{65}$ and to the 'stricter' line followed by Ugolino Verino (1438-1516), Maffeo Vegio (1407-1458) and others, whose references to the ancient world or mythology are less prominent and always subordinated to the religious and theological substance. ${ }^{66}$

Even partisans of the former approach did not regard as insignificant or innocuous the proliferation of pagan names in their own (and their predecessors') poetry. This passage by Sannazaro (as late as 1521) is eloquent enough:

... senza qualche lepore poetico non mi aggradaria di tractare questa materia: basta che la Vergine non è chiamata nympha né Cristo figlio di Giove o Apollo, come il chiama il Petrarca: 'Lavit apollineos ad ripam fluminis artus': questo ben credo io che saria errore. De le cose, che non guastano la religione et si ponno fingere senza scandalo, non mi son guardato, anzi con sommo studio le ho affettate, per non fare ne forte tumultus surgeret in populo. ${ }^{67}$

[ ... I would not be pleased to tackle this topic without some poetic grace: it is sufficient that the Virgin is not called a 'nymph', nor Christ the son of Jupiter or Apollo, as Petrarch does: 'he washed his Apolline limbs on the shore of the river' (Bucolicum carmen I.66), for this I would deem an error. I did not refrain from the fictions which do not offend religion and which can be employed without scandal, indeed I used them in a very skillful manner, so that 'a popular uproar would not arise'.]

As late as 1578, the synod of the French Reformed church was so concerned about this practice as to circulate prescriptions on the topic, in the very country where Pierre de Ronsard (1524-1585) and the Pléiade had proliferated references to the pagan gods: ${ }^{68}$

Ceux qui mettent la main à la plume pour traiter en poesie l'histoire de l'Escriture Sainte, sont avertis de n'y mesler les fables poetiques et de n'attribuer à Dieu le nom des faux dieux et de n'ajouter ou diminuer à l'Escriture Sainte, mais de se tenir à peu près à ses termes. ${ }^{69}$

\footnotetext{
64 The 'fundamentalist' stance taken by Dominici and Savonarola - on which see Verino, Epigrammi, ed. Bausi (n. 57 above), pp. 62-100 - is, of course, not taken into account here.

65 See J. Burckhardt, The Civilisation of Renaissance in Italy, New York, 1954, III.12; C. Marsico, 'Dii veteres fugere', in Allusions and Reflections - Greek and Roman Mythology in Renaissance Europe, ed. E. Wåghäll Nivre, Cambridge, 2015, pp. 347-63.

66 Verino, Epigrammi, ed. Bausi (n. 57 above), pp. 101-23.

67 Jacopo Sannazaro, letter to Antonio Seripando (13 April 1521) about the De partu Virginis, in id., De partu Virginis, ed. C. Fantazzi and A. Perosa, Florence, 1988, p. 93. On the broader issue, see R. Béhar, 'Virgilio, San Agustín y el problema del poema heróico cristiano (1520-1530)', Criticón, 107, 2009, pp. 57-92, esp. p. 66.

68 Pierre de Ronsard, Hymne à la Justice, ed. P. Laumonier, Paris, 1966, 11. 473-6: 'Jupiter, Pallas, Apollon sont les noms / Que le seul Dieu reçoit, et meintes nations / pour ses divers effectz que l'on ne peut comprendre, / si par mille surnoms on ne les fait entendre.'

69 Synod of the French Reformed church, 1578, quoted in Buck, L' eredità classica (n. 51 above), p. 269; see État religieux et légal des protestants en France, Paris, 1822, XIV.1.17.
} 
[Those who take up a pen in order to narrate in verse the stories of the Holy Scripture are required not to mingle poetic fables, nor to attribute to God the name of the false gods, nor to add or detract from the Holy Writ, but to stick as much as possible to its wording.]

\section{Hellenic Verse and Christian Humanism: Filelfo, Poliziano, Musurus}

Greek versification on Italian soil in the fifteenth and early sixteenth century is a phenomenon which still awaits a proper assessment, although it definitely represents a very intriguing snapshot of the basic tenets of humanism. Any future inquiry in this area will profit from the comparison with the late ancient and medieval background which I have briefly sketched, for the dialectics of cultural dialogue and controversial appropriation of Hellenism in both periods sometimes present striking similarities. ${ }^{70}$ In what follows, I shall present three authors belonging to three different generations of humanists: all of them, in very different ways, attempt to construct a plausible Hellenic poetry in a learned Christian world.

Francesco Filelfo's (1398-1481) De psychagogia is simultaneously the first and the least satisfying attempt by a Western humanist to write Greek verse, especially as far as the linguistic, rhetorical and poetical aspects are concerned. ${ }^{71}$ Despite his

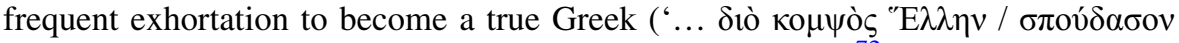
हiv่ul'; 'therefore strive to become / an accomplished Greek'), ${ }^{72}$ and his boasting that he would be the first Italian not merely to try his hand at imitating Homer and Alcaeus, but to publish a substantial collection of poems in classical Greek, ${ }^{73}$ Filelfo himself knew that he was not a champion of hellenismos, even if he had spent seven years in Constantinople (1420-1427) and was thus one of the few Italian humanists to have gained direct access to the living tradition of Greek culture: ' $\Lambda \alpha \tau i v o \zeta \gamma$ $\alpha$

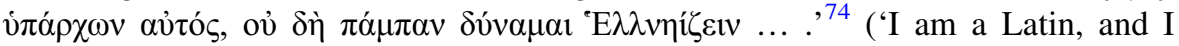
cannot speak Greek perfectly'). We still await a thorough stylistic and ideological analysis of Filelfo's mostly unattractive poems, which all follow two metrical structures: alternatively elegiac couplets and Sapphic stanzas. ${ }^{75}$ At first glance, the presence of Greek mythology and nomenclature (and thought) seems rather

\footnotetext{
${ }^{70}$ For a first outline of Greek versification in Renaissance Italy, see F. Pontani, 'Graeca per Italiae fines', in Hellenisti! Altgriechisch als Literatursprache im neuzeitlichen Europa, ed. S. Weise, Stuttgart, 2017, pp. 311-47, esp. pp. 311-21. A comparative approach between late antiquity and the Renaissance in other respects was applied programmatically in the articles collected in Antiquity Renewed: Late Classical and Early Modern Themes, ed. Z. R. W. M. von Martels and V. M. Schmidt, Leuven, 2003.

71 The sylloge was first published in Francesco Filelfo, De psychagogia, ed. G. Cortassa and E. V. Maltese, Alessandria, 1997. See also E. V. Maltese, 'Appunti sull'inedita Psychagogia di Francesco Filelfo', Res Publica Litterarum, 12, 1989, pp. 105-13.

72 Filelfo, De psychagogia (n. 71 above), pp. 59-60 (I.12); this poem was written around 1457 for Donato Acciaiuoli, Palla Strozzi's son-in-law and John Argyropoulos's pupil.

73 See D. Robin, Filelfo in Milan, Princeton, 1991, p. 120.

74 This is letter PhE XIII.62 (to John Argyropoulos, of 5 November 1457) in Francesco Filelfo, Collected Letters (Epistolarum libri xlviii), ed. J. De Keyser, II, Alessandria, 2015, p. 648.

75 Cortassa and Maltese's invaluable editio princeps is a faithful reproduction of the autograph, with some interesting linguistic notes. There are also some useful hints in Robin, Filelfo (n. 73 above),
} 
superficial: the mention of Olympus and Hades, of Helicon and the Muses, of Ares and Poseidon, ends up as little more than lip-service to antonomastic deities or as a hyperbolic term of comparison for the addressee, even when (as is often the case) this is a pope or a high dignitary of the ecclesiastical hierarchy. ${ }^{76}$

A good case in point is Psychagogia II.12, an epitaph written in 1458 for the death of Alfonso of Aragon, king of Naples: this poem ends on a very strong encomiastic note, by juxtaposing the Hellenic and Christian heritage in two contiguous stanzas (11. 69-76).

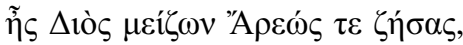

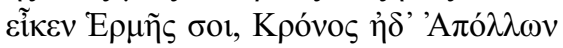

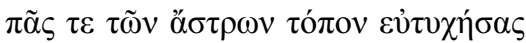

$\pi \rho \alpha ́ \xi \varepsilon \omega \varsigma$ है $\rho \gamma \omega$.

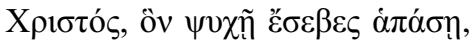

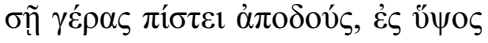

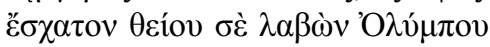

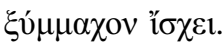

[While alive, you were greater than Zeus and Ares, / and Hermes, Kronos, Apollo, and all those / who had a place among the stars yielded to you / (72) in effectiveness of action.

Christ, whom you revered with all your soul, / awarded a prize to your faith and brought you, / as his ally, to the extreme height / (76) of divine Olympus.]

Usurpation is here a Stilprinzip, but the juxtaposition is rather cold and mechanical, and it fails to achieve a proper aesthetic integration of pagan and modern theology and imagery.

A younger and far more skilled Western author of Greek verse was Angelo Poliziano (1454-1494), who produced a number of epigrams (posthumously collected in a Liber epigrammatum Graecorum, which he himself had at least partly designed) in various periods of his life and which display a varying degree of technical and literary expertise. ${ }^{77}$ We are lucky enough to possess at least one document of Poliziano's commitment to religious poetry stricto sensu: Epigram IX was written when he was 18 years old, and it belongs to the first wave of his output, marked by a certain immaturity of style and diction, but also by a surprising ability to assimilate and blend different literary traditions, well beyond the limits of the genre. Epigram IX, as stated in its title, consists of a prayer to God which bears some similarity to the Pater noster: it should be noted, however, that the initial and final invocation is rewritten along the Homeric pattern of the invocation to Zeus in the Iliad:

\footnotetext{
Footnote 75 continued

pp. 125-37. On Filelfo's fondness for metrical variety, see Francesco Filelfo, Odes, ed. D. Robin, Cambridge MA and London, 2009, pp. xx-xxi.

76 E.g., Borso d'Este in De psychagogia (n. 71 above), I.4; and Cardinal Bessarion in II.7.

77 See Angelo Poliziano, Liber epigrammatum Graecorum, ed. F. Pontani, Rome, 2002.
} 


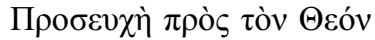

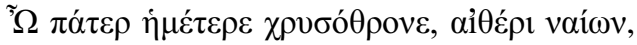

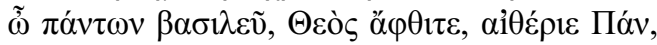

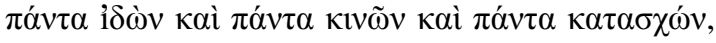

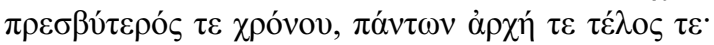

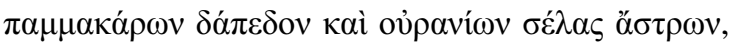

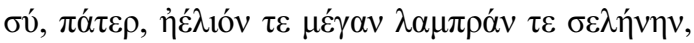

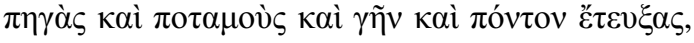

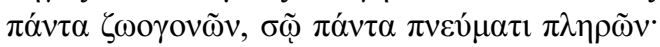

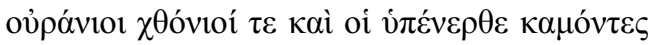

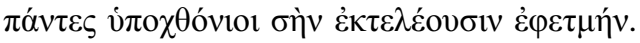

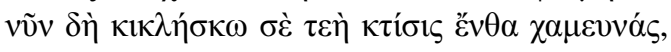

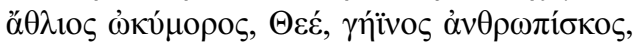

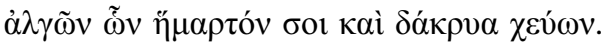

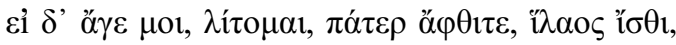

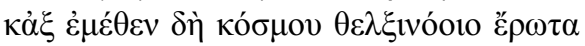

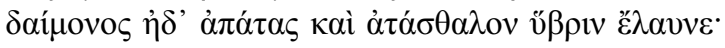

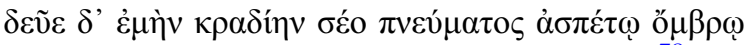

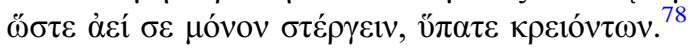

[Prayer to God

Our Father living in the aether on a golden throne, / king of all, immortal God, ethereal Pan, / you who see, move and own everything, / older than time, beginning and end of all things: / (5) you, Father, made the floor of the blessed / and the splendour of heavenly stars, the great sun and the bright moon, / the springs and the rivers, the earth and the sea, / giving life to everything, filling everything by your spirit; / those living in heaven and on earth, and the dead below, / (10) under the earth, all execute your order. / Now I invoke you, here, your creature lying on the ground, / a small, wretched, quickly-dying man made of earth, / suffering and shedding tears for my sins against you. / Please, infinite Father, be gracious towards me, / (15) and drive away from me the love of the heart-enchanting world, / the frauds of the devil and the reckless insolence: / cleanse my heart through the unceasing rain of your spirit / so that I may love you alone, o highest of rulers.]

COMPARANDA

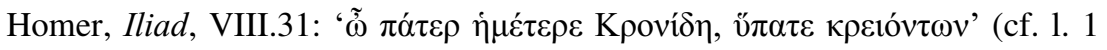
and 18)

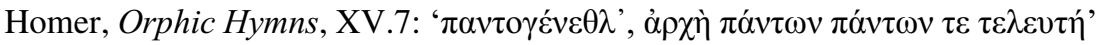

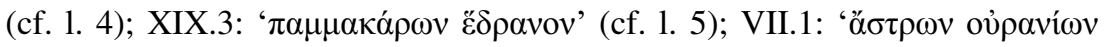

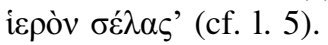

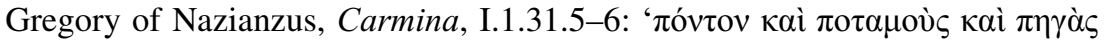

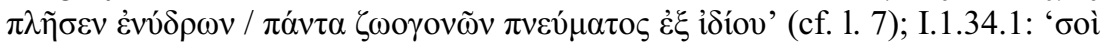

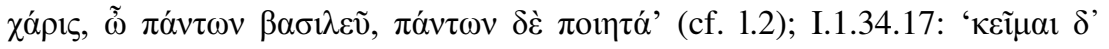

78 On Poliziano's sources, see ibid., pp. xxxi-xlii. 


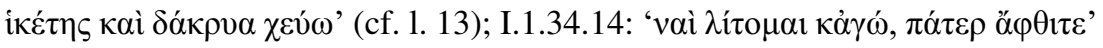
(cf. 1. 14)

While Friedrich Otto Mencke (1708-1754), the author of an influential biography of Poliziano in the eighteenth century, regarded this epigram as clear proof of Poliziano's Christian faith, ${ }^{79}$ it consists of a sort of loose paraphrase (it is neither a cento nor a word-by-word paraphrase), which does not draw directly on any earlier Greek text: there is no evidence that Poliziano ever had access to Nonnus's Paraphrase of the Gospel of St John, ${ }^{80}$ and no truly comparable attempt appears to have been produced in Byzantium. ${ }^{81}$ In fact, the epigram is heavily indebted to both pagan and Christian sources: among the former (apart from Homer) an important role is played by the Orphic Hymns, particularly concerning Zeus, the father of the gods (see 11. 4 and 5). Among Christian sources, two poems of Gregory of Nazianzus stand out: Carmen I.1.31 provides the model for 1. 7, and Carmen I.1.34 for 1l. 2, 13 and 14. Both these poems were accessible to Poliziano in a (now lost) manuscript also known to Marsilio Ficino (1433-1499), who copied Gregory's texts in MS Vatican City, Biblioteca Apostolica Vaticana, Vat. Borg. Gr. 22. ${ }^{82}$

This contamination and cross-fertilization of the pagan and the Christian tradition, of Homer and Gregory, also implying a debt to the Orphic and Neoplatonic trends so widely represented among the contemporary Florentine élite, recalls the issues discussed above in the first section. Poliziano's Pater noster has no doctrinal or exegetical meaning, much less a didactic intention: rather than linking it to his participation in the 'Compagnia del Vangelista' in Florence, we should probably regard it as a virtuoso tour de force designed to display Poliziano's deep acquaintance with ancient Greek poetry and with very heterogeneous sources - a characteristic of his learning which will later come to the fore, particularly in the Miscellanea.

This epigram, written in Neoplatonic Florence, is, however, witness to a climate of cultural confrontation between a resilient paganism (with a burgeoning interest in Greek language culture) and a dominant Christian ideology, which shares some common features with the complicated cultural crossroads of fifth-century Egypt. As I have indicated, there is no question of a direct inspiration from Nonnus of Panopolis - an author whom Poliziano discovered much later in his career (and

\footnotetext{
79 F. O. Mencke, Historia vitae et in litteris meritorum Angeli Politiani, Leipzig, 1736, p. 448. This idea has been subsequently rejected on the basis of the scarcity and the poor inspiration of the author's other religious output: see already I. Del Lungo, Florentia, Florence, 1897, p. 201; a much needed study of Poliziano's scholarly reception is currently being prepared by Jaspreet Singh Boparai. On Poliziano's religious dimension, see now M. Accame Lanzillotta, Poliziano traduttore di Atanasio, Tivoli, 2012.

${ }^{80}$ Where the Pater Noster is, of course, absent, since that prayer only appears in the Gospels of Matthew and Luke; on Poliziano and Nonnus, see G. Agosti, 'Prima fortuna umanistica di Nonno', in Vetustatis indagator: scritti offerti a Filippo Di Benedetto, ed. V. Fera and A. Guida, Messina, 1999, pp. 89-114 (105-8).

81 See Poliziano, Liber epigrammatum, ed. Pontani (n. 77 above), pp. 39-40.

82 Ficino's copy is today the sole extant witness of these hymns, along with the much later MS Vienna, Österreichische Nationalbibliothek, Vind. Theol. Gr. 43; see M. Sicherl, 'Zwei Autographen Marsilio Ficinos: Borg. Gr. 22 und Paris. Gr. 1256', in Marsilio Ficino e il ritorno di Platone, ed. G. C. Garfagnini, I, Florence, 1986, pp. 221-8.
} 
probably was the first to identify as both the author of the Dionysiaca and a poeta Christianus) ${ }^{83}$ the similarities I am pointing at go beyond textual affinities and involve a broader analogy between two changing worlds, where the tension between Hellenism as form and Hellenism as content is a paramount element for the shaping of a new poetic texture.

A generation younger than Poliziano, the Cretan scholar Marcus Musurus (c. 1475-1517) spent a long time in Italy (Florence, Carpi, Padua, Venice and Rome) as a scribe and a successful teacher. ${ }^{84}$ His importance goes far beyond his remarkable skill in textual criticism, which earned him well-deserved fame as the best emendatory talent among the Greeks: ${ }^{85}$ to his merits as a scholar and teacher, we should also add his ability as a versifier in the encomiastic and epideictic genre (often poésies d'occasion or Buchepigramme). ${ }^{86}$ His best achievement in the epideictic field was beyond doubt the long Ode to Plato, printed together with Aldus's letter at the beginning of the editio princeps of Plato in $1513:{ }^{87}$ we see here

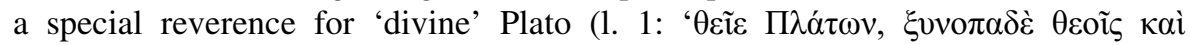

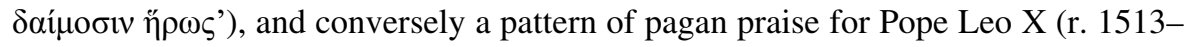

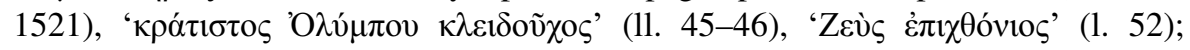
stylistically, the whole ode is cast into a dense web of pagan imagery, literary allusions and subtle quotations, which projects Kontrastimitation into a discourse of assimilation between ancient and modern ideals.

This is all the more remarkable since the Ode to Plato contains a prosopopoea of the Athenian philosopher, a symbol of that ancient Greek culture now endangered by the Turkish conquest and thus the most credible and authoritative voice to explain to the pope why he should hasten to organize a crusade against the infidels and to create a centre for Hellenic learning in Rome. ${ }^{88}$ Crucially, this ode envisages a way to bridge the ideological gap between the pagan and the Christian world by way of cultural cooperation, the same ideal which inspired the agenda of the most important printer of classical texts in Italian humanism, Aldus Manutius, who is

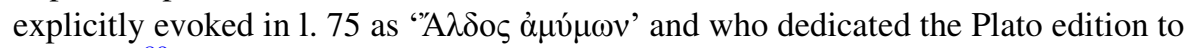
the pope. ${ }^{89}$

\footnotetext{
${ }^{83}$ Agosti, 'Prima fortuna' (n. 80 above), pp. 105-8.

${ }^{84}$ Essential elements concerning his biography, scribal activity and intellectual life have recently been provided by L. Ferreri, L'Italia degli umanisti, 1: Marco Musuro, Turnhout, 2014, and D. Speranzi, Marco Musuro. Libri e scrittura, Rome, 2013.

${ }^{85}$ U. von Wilamowitz-Moellendorff, Euripides. Herakles, I, Berlin, 1959, p. 221. See now Ferreri, Marco Musuro (n. 84 above), pp. 17-18.

${ }^{86}$ See F. M. Pontani, 'Epigrammi inediti di Marco Musuro', Archeologia classica, 25-6, 1973-1974, pp. 575-84; Ferreri, L'Italia (n. 84 above), passim.

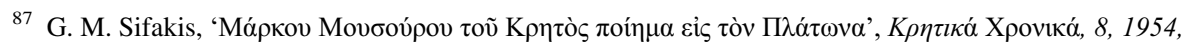
pp. 366-88, and Ferreri, Marco Musuro (n. 84 above), pp. 140-51. See now Aldus Manutius, The Greek Classics, transl. N. G. Wilson, Cambridge MA and London 2016, pp. 302-17.

${ }^{88}$ This would be the short-lived Collegio greco, opened under the aegis of Musurus and Janus Lascaris between 1517 and 1519; see S. Pagliaroli, 'Giano Lascaris e il Ginnasio greco', Studi Medievali e Umanistici, 2, 2004, pp. 215-93; Le prime edizioni greche a Roma (1510-1526), ed. C. Bianca, S. delle Donne, L. Ferreri and A. Gaspari, Turnhout, 2017.

${ }^{89}$ C. Dionisotti, Aldo Manuzio umanista e editore, Milan, 1995; M. Lowry, The World of Aldus Manutius, Oxford, 1979, p. 205.
} 
Although addressed to a pope, the Ode to Plato is no religious elegy. Musurus experimented with a truly new dimension of Christian poetry only in two little known paraphrases of pivotal liturgical texts, the Creed and the Ave Maria. ${ }^{90}$ Both these poems (which are prayers, not narratives) exhibit a structural blend between pagan terminology and formulas, ${ }^{91}$ on the one hand, and a distinctive understanding of the doctrinal interpretation of Christian dogmas or evangelical stories, on the other. ${ }^{92}$ I have commented elsewhere on the deep exegetical thrust of Musurus's Creed, especially when read against the background of the hot theological debate on the Filioque and on the different versions of the Nicaeno-Constantinopolitan formula. ${ }^{93}$ Musurus's poem, bulging with learned references to remote vocabulary, to forgotten glosses and to the entire spectrum of pagan hexametric poetry, surpasses Poliziano's attempts because it skilfully appropriates the whole of the Hellenic heritage, and it exploits the epic mould in order to shape in beautiful rhetorical terms the dogmas of the Christian faith. I quote here a short passage:

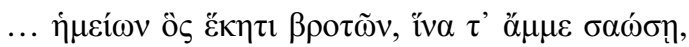

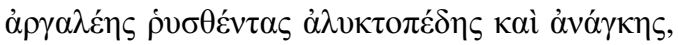

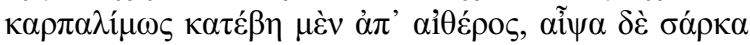

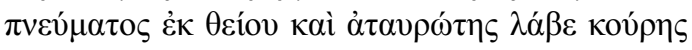

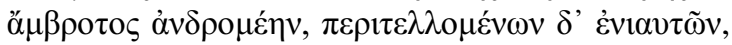

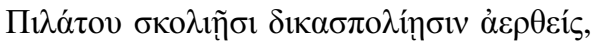

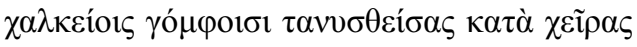

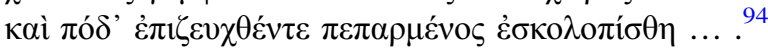

[He descended swiftly from the aether for the sake of us mortals, / in order to save us and to protect us from the terrible / (10) bonds and necessity, and suddenly, although immortal, / he wore mortal flesh by way of the Holy Spirit / and of a virgin girl, and as the years came round, / he was lifted up because of Pilatus's crooked judgements / and crucified with his open hands and his crossed feet / (15) pierced by bronze nails.]

COMPARANDA

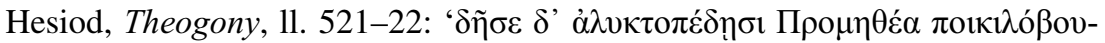

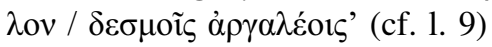

\footnotetext{
90 See F. Pontani, 'Musurus' Creed', Greek, Roman and Byzantine Studies, 43, 2002-2003, pp. 175-213; F. Pontani, 'Preghiere, parafrasi e grammatiche: il Credo e l'Ave Maria di Marco Musuro', Bibliothèque d'Humanisme et Renaissance, 76, 2014, pp. 325-40. I add here that Musurus' Creed also appears in ff. 36r-38r of ms. Par. suppl. gr. 1254 (late 16th c.), where it is wrongly ascribed to an otherwise unknown Ioannes Choniates.

91 The Olympus, the Erinyes, the erebos; the stylistic features derive from epic prototypes of different ages, from Homer and the Homeric Hymns to Apollonius Rhodius and Quintus Smyrnaeus.

92 The procession of the Holy Spirit, the Crucifixion, the Anastasis or Resurrection, are amplified ad hoc, often along the lines of Nonnus of Panopolis's interpretation.

93 Pontani, 'Musurus' Creed' (n. 90 above), pp. 191-6.

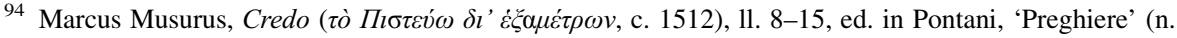

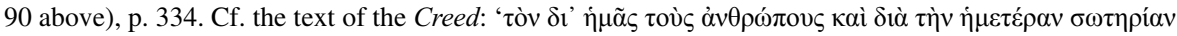

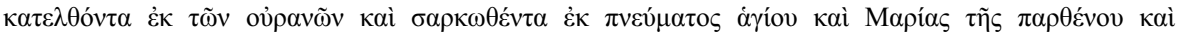

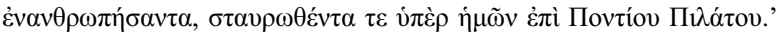


Aristophanes, Lysistrata, 1. 217: 'oǔko1 $\delta$ ’ $\alpha \alpha$

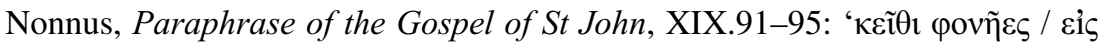

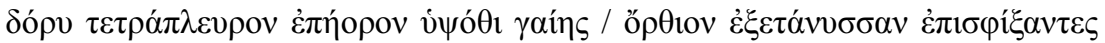

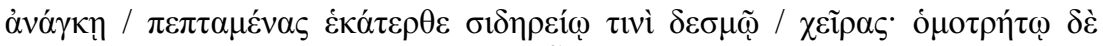

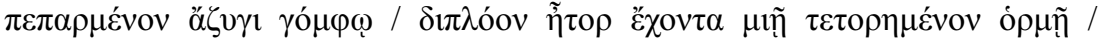
$\pi$

These few lines eloquently show the interlacing of different models, drawn from the entire spectrum of ancient Greek literature: mankind's chains in 1.9 reproduce those used for Prometheus in Hesiod's Theogony; the description of the Virgin as

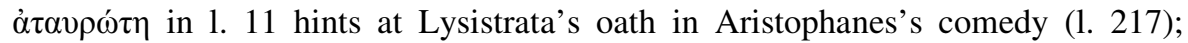
several formulas recall Homer (' $\kappa \alpha \rho \pi \alpha \lambda i \mu \omega \varsigma$ ' at the beginning of a line: $I l$. I.359

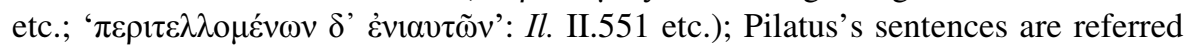

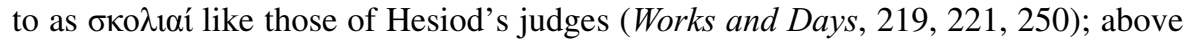
all, the entire digression on Christ's crucifixion - an addition to the prayer's wording - is heavily indebted to the related account in Nonnus's Paraphrase of the Gospel of St John (XIX.91-95).

In Musurus's newly discovered Ave Maria, we see a similar phenomenon:

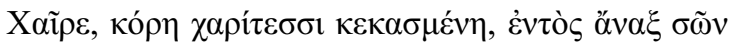

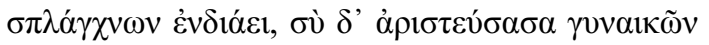

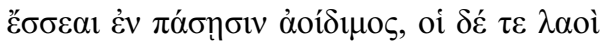

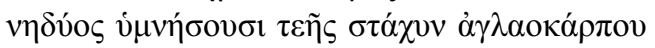

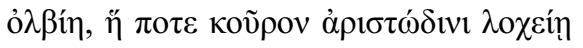

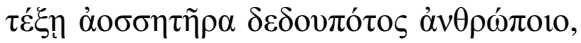

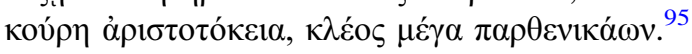

[Hail, maiden replete with graces, the Lord lives / in your inward parts, and, as the most distinguished of women, / you will be famous among all, and the peoples / will celebrate the progeny of your magnificently fertile womb, / (5) blessed you, who will generate one day, through a most illustrious childbirth, / a baby who will save fallen man, / o maiden of illustrious offspring, great renown of the virgins.]

\section{Comparanda}

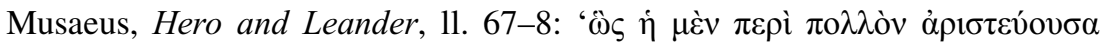

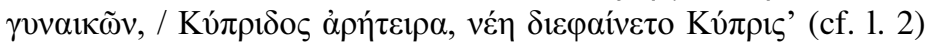

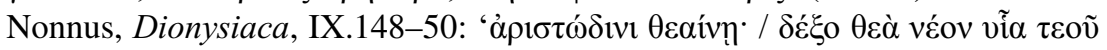

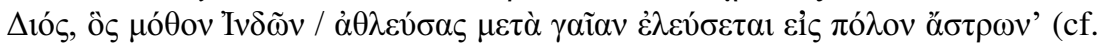
1. 5)

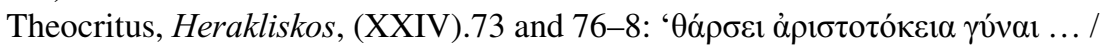

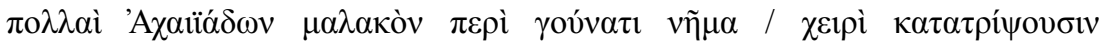

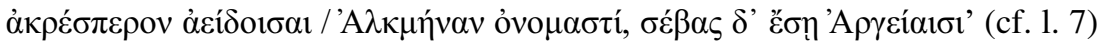

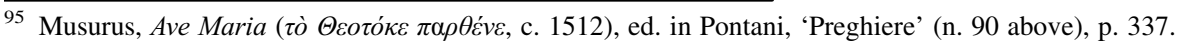

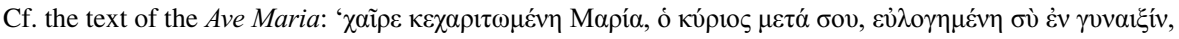

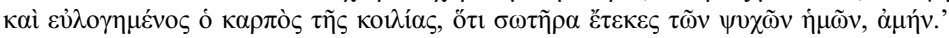


Here, while pursuing the appropriation of Nonnian formulae (derived from both the Dionysiaca and the Paraphrase), Musurus, by means of subtle allusions, openly contaminates the Virgin Mary, first, with Hero, the altera Venus who dominates Musaeus's epyllion Hero and Leander (1. 2); then, with Rhea, the mother of Zeus who in Nonnus's Dionysiaca is informed by Hermes of the birth of her grandson Dionysus, a figura Christi par excellence (1. 5); and, finally (1. 7), with Theocritus's Alcmena, who - as the mother of Heracles, another figura Christi since appearing in late ancient mosaics and poetry ${ }^{96}$ - will be greeted and celebrated by the Greek women in the Herakliskos. Musurus does not attempt to adopt gratuitous antonomastic terminologies or empty references to a bookish world: we have here Kontrastimitation in the purest sense of paraphrastic poetry as shaped since late antiquity, and it is, of course, not by chance that Nonnus plays such an important role. Christian dogmas and narratives are clad in pagan dress, with a series of more or less overt, and often contrasting, references to ancient passages, so as to finalize a cultural dialogue designed to represent a watershed in Western literary culture.

The immediate purpose of Musurus in writing these sui generis paraphrases remains partly mysterious: we know that he had links to the Greek Orthodox community of Venice ('E appointed archbishop of Monemvasia in 1516, but also that he was not particularly interested in religious issues. ${ }^{97}$ What is striking, however, is that although these paraphrases did obtain - to a very limited extent - the honour of publication, they did so not as autonomous texts or in a poetic sylloge, but rather as the opening paratexts in a bifolium bound with some of the extant copies of the second edition of Urbano Bolzanio's (1442-1524) Institutiones grammaticae (1512), the first Greek grammar in Latin to appear in print. ${ }^{98}$

For all the caution we may adopt in evincing a connection with their material context, it is a priori reasonable to assume that these religious poems - due to their undeniable stylistic analogies with the Ode to Plato - should date precisely from about the period of the revised edition of Bolzanio's grammar: indeed, they were probably intended from the very start as introductory pieces to that book. In medieval Latin grammars, the incipit was generally occupied by the so-called 'Salterio', a collection of prayers and religious texts: a similar collection (in bilingual, Graeco-Latin form) also featured in Roger Bacon's (c. 1214-c. 1292) long forgotten Greek grammar, as well as, more recently, in Aldus Manutius's Institutiones Graecae grammaticae, namely in its very influential Appendix of elementary Christian Greek texts. ${ }^{99}$

If this is correct, Musurus might thereby have implicitly suggested a new approach to language learning by way of expressly created texts, which fulfilled the

\footnotetext{
96 Bowersock, Hellenism (n. 2 above), pp. 46-9.

97 A. Cataldi Palau, 'La vita di Marco Musuro alla luce di documenti e manoscritti', Italia Medioevale e Umanistica, 45, 2004, pp. 295-369 (343-8).

98 Pontani, 'Preghiere' (n. 90 above), pp. 325-33.

99 P. Botley, Learning Greek in Western Europe 1396-1529, Philadelphia, 2010, p. 74; F. Ciccolella, 'Greek Grammars and Elementary Readings in the Italian Renaissance', in Libri di scuola e pratiche didattiche dall'antichità al Rinascimento, ed. L. del Corso and O. Pecere, Cassino, 2010, pp. 577-605.
} 
same purpose as the works of the Apollinarioi in the fifth century AD: to 'ennoble' a Christian content by means of a learned, highly sophisticated and allusive 'ancient' style. This idea shows similarities to Aldus Manutius's statement about the need to familiarize Latin pupils with the main texts of Christian liturgy along the old principle of the hominum utilitas. ${ }^{100}$

Carlo Dionisotti has insisted on Aldus's religious spirit and on the continuous references to his Christian faith in the prefaces to his editiones principes of the pagan classics. ${ }^{101}$ What is certain is that at the turn of the century the Aldine press for which Musurus was one of the most important collaborators - launched the immensely laborious project of the Poëtae Christiani Veteres, ${ }^{102}$ which included, first of all, several Latin poets (including biblical paraphrases), then, in volumes II and III, the Homeric centos and the poetry of Gregory of Nazianzus, ${ }^{103}$ and finally, in volume IV (which was probably never published officially, although several copies must have circulated among Aldus's friends), Nonnus's Paraphrase of the Gospel of St John. ${ }^{104}$ All the Greek texts of the Poëtae, except Nonnus's Paraphrase, were equipped with facing Latin translations, 'ad graecarum literarum rudium utilitatem, quae tamen tralatio si cui libuerit separare a graeco potest pro arbitrio suo'. 105

This enterprise was consistent with Aldus's ideal as a printer and homme de lettres, described by Dionisotti as 'la proposta, che prima si era levata solo dalla cattedra universitaria del Poliziano, ripetuta e confermata ora ad altro livello, per un altro pubblico, di un culto della poesia nelle tre lingue, greca latina e volgare'. ${ }^{106}$

Nam sanctissimos libros, qui circiter mille annos latuere, publicavimus, ut amentur leganturque in scholis, fiatque non ut antehac, cum fabulae, quibus tenera puerorum aetas imbuitur, pro historia habebantur - quae est potissima, ut puto, causa quod quam plurimi e doctis et vitiosi sunt et infideles -, sed contra pro falsis falsa habeantur et vera pro veris .... . Quod tamen facillime spero futurum, si a teneris annis hosce Christianos poetas pueri doceantur imbuanturque divinis. Nam, cum ad gentiles iam bene instituti legendos se conferent, bona quaecunque invenerint legendis illis, ut e spinis rosas et id

\footnotetext{
100 In the famous preface to his 1495 edition of Constantine Lascaris's Erotemata - see Aldus Manutius, Greek Classics, ed. Wilson (n. 87 above), p. 6; but there were also hints in Justin Dekadyos's preface to the 1494 Psalter; see Aldo Manuzio editore, ed. G. Orlandi and C. Dionisotti, I, Milan, 1975, p. 4.

101 Dionisotti, Aldo Manuzio (n. 89 above), pp. 106-7.

102 On the saga of this editorial project, see Lowry, The World (n. 89 above), pp. 148-9; C. Vecce, 'Aldo Manuce [sic] et les découvertes de manuscrits', in Les humanistes et l'antiquité grecque, ed. R. Aulotte and M. Ishigami, Paris, 1989, pp. 147-56 (149).

103 The second volume of Poëtae Christiani veteres is the first of Aldus's books to bear the anchor and dolphin emblem, with the famous motto 'Festina lente'.

104 The 'Nonni poëtae Panopolitani Paraphrasis ... carmine heroico excellenti' is quoted in the 1503 and 1513 catalogues of the Aldine editions: Agosti, 'Prima fortuna' (n. 80 above), pp. 109-14; M. Lowry, Il mondo di Aldo Manuzio, Rome, 2000, p. 352.

105 This statement is in the 1503 catalogue, for which see Aldo Manuzio tipografo 1494-1515, ed. L. Bigliazzi et al., Florence, 1994, p. 119, but not in the 1513 list, ibid., p. 166.

106 Dionisotti, Aldo Manuzio (n. 89 above), p. 132.
} 
genus flores, accipient; mala vero et quae moribus obsunt, prudentes, tanquam scopulum, evitabunt. ${ }^{107}$

[We have published these sacrosanct books, which had remained hidden for about 1000 years, so that they may be read and appreciated in schools and that the myths by which children are fed from a tender age may no long be considered as truths (which is why - in my opinion - so many learned men incline to vice and impiety), but false things may appear as false and true ones as true ... . I expect this to come about very easily, if children are taught these Christian poets from their early years, while being instructed in divine matters. For if they turn to read pagan poets with a suitable background, they will receive all the advantages which they find in reading them, just like roses (and similar flowers) among thorns, but they will prudently avoid their evil and immoral features, just like rocks.]

The project of the Poëtae Christiani veteres had a rationale similar to that of the paraphrases and the Christian adaptations of pagan poetry produced in the framework of late ancient civilization. And just like the works of one of the Apollinarioi in Socrates's account, Musurus's texts are related to a grammatical text. It seems reasonable to assume, however, that pupils and schoolboys were not among his primary intended readership: more plausible candidates are the community of the Greeks gathering around the church of San Giorgio dei Greci or the wider public of learned humanists fond of ancient hexameters. ${ }^{108}$ Whatever the case, do we not face a similar dilemma (schoolboys / simple believers / learned scholars) when considering potential readers of the Christian poetry of late antiquity?

Just like the Christians of late antiquity, humanists (and especially those working in Aldus's entourage) thought about ways to strike a balance between their religious commitment and the dominance of pagan literature in their milieu. ${ }^{109}$ Hellenism, in the full span of its linguistic and literary resources, served as a response to the inadequacy of Christian rhetorical and poetic elaboration: not in order to 'replace' the texts of the pagan curriculum (which were gradually being rediscovered and constituted the heart of humanist instruction), but in order to secure the primacy of the Christian faith and to construct a cultural discourse conducive to a 'Christianity that did not involve rejecting too much of the past'. ${ }^{110}$

\footnotetext{
107 Aldus Manutius, preface to the 1501 edition of Sedulius, Iuvencus and Arator (Poëtae Christiani veteres, I), in Aldo Manuzio editore (n. 100 above), I, p. 36. A very similar point is made in the 1501 volume with Prudentius, Prosperus, John of Damascus, ibid., p. 34: '... statui Christianos poetas cura nostra impressos publicare, ut loco fabularum et librorum gentilium infirma puerorum aetas illis imbueretur, ut vera pro veris et pro falsis falsa cognosceret, atque ita adolescentuli non in pravos et in infideles, quales hodie plurimi, sed in probos atque orthodoxos viros evaderent, quia adeo a teneris assuescere multum est ... .' See also the preface to Gregory's Carmina cum versione Latina of 1504 (Poëtae Christiani veteres, III), ibid., p. 81: 'nam et Graece simul discetis et Christiane vivere, quandoquidem summa in illis et doctrina est et gratia, et sanctis moribus mire instituunt adolescentes' . 108 Pontani, 'Preghiere' (n. 90 above), pp. 332-3.

109 A comparison between these two historical ages has been sketched by Liebeschuetz, 'Pagan Mythology' (n. 34 above), pp. 193-5.

110 Cameron, 'Poets and Pagans' (n. 4 above), p. 39; already quoted at n. 20 above.
} 
Did humanists show any awareness of this potential parallel with late antiquity? The answer is, predictably, largely negative. One text may stand apart, and it is again a poetical text, by the most outstanding Greek philologist, book-hunter, traveller and diplomat working in Italy and France between the fifteenth and sixteenth century: Janus Lascaris (c. 1445-1535). ${ }^{111}$ An exquisite connoisseur of the most remote corners of ancient Greek literature, Lascaris was the author of a large collection of highly elaborated and often very allusive Greek epigrams, ${ }^{112}$ as well as of a recently discovered Sapphic ode to King Charles VIII, in which he supported the idea of a crusade against the Turks (the same topic later tackled by Musurus in his Ode to Plato) by evoking a no less pagan imagery than Hesiod's golden age (Tethys, Bacchus and Athena are mentioned, and God is described as Zeus 'father of the thunders and the gods'). ${ }^{113}$

Throughout his poetic output, as well as in his own broader cultural and political activity, Lascaris never renounced his Hellenic background and education, and continuously envisaged the blending of pagan form (at a very high level of refinement) and Christian content. It might thus not be by chance that he devoted one of his epigrams precisely to Julian's edict of 362 and indirectly to the reaction of Gregory of Nazianzus with which I started this survey:

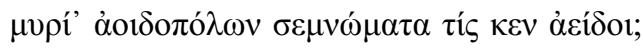

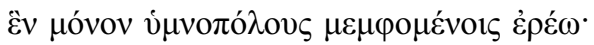

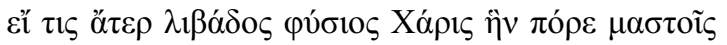

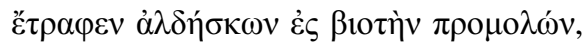

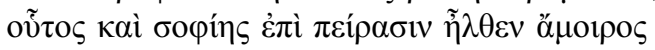

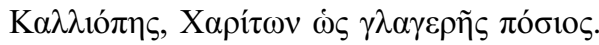

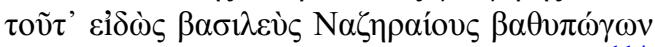

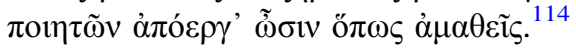

[Who could sing the innumerable dignities of the poets?

I shall say one thing only to those who blame them:

if anyone who has come to life has grown up being reared without

the natural liquid poured by the Grace's breasts,

that man has reached the limits of science remaining unaware of Calliope, just as of the Graces' milky drink.

Knowing this, the long-bearded emperor kept the Nazarenes away from the poets, so that they remain ignorant.]

\footnotetext{
${ }^{111}$ On his biography, see Pagliaroli, 'Giano Lascaris' (n. 88 above); M. Ceresa, 'Lascaris, Giano', in Dizionario biografico degli Italiani, LXIII, Rome, 2004, pp. 785-91; A. Pontani, 'Per la biografia, le lettere, i codici di Giano Làskaris', in Dotti bizantini e libri greci nell'Italia del secolo XV, ed. M. Cortesi and E. V. Maltese, Naples, 1992, pp. 363-433.

112 Janus Lascaris, Epigrammi greci, ed. A. Meschini, Padua, 1976; M. Lauxtermann, 'Janus Lascaris and the Greek Anthology', in The Neo-Latin Epigram, ed. S. T. M. de Beer, K. A. E. Enenkel and D. Rijser, Leuven, 2009, pp. 42-65.

${ }^{113}$ F. Pontani, 'Sognando la crociata: un'ode saffica di Giano Làskaris su Carlo VIII', Italia Medioevale e Umanistica, 56, 2015, pp. 251-94.

${ }^{114}$ Lascaris, Epigrammi, ed. Meschini (n. 112 above), p. 80.
} 
In Gregory's times - we are reminded - 'while a few extremists condemned all classical literature, for most Christians it was quite literally the culture of the world'. ${ }^{115}$ In the humanist period, that same literature was being slowly rediscovered and placed at the centre of the educational and cultural system: Lascaris condemns Julian not - as was customary throughout the Byzantine era ${ }^{116}$ because of his apostasy and paganism, but rather because he had tried to sever the transmission of classical culture to the Christian world. In humanist times, Hellenism had to live a new life and to circulate again not only among the learned élites but in all classrooms and souls, becoming once again 'the culture of the world'.

\footnotetext{
115 Cameron, 'Poets and Pagans' (n. 4 above), p. 29.

116 See S. Trovato, Antieroe dai molti volti: Giuliano l'Apostata nel Medioevo Bizantino, Udine, 2014.
} 